\title{
IN VITRO ANTIMALARIAL ACTIVITY OF SOME ORGANOTIN(IV)2-NITROBENZOATE COMPOUNDS AGAINST PLASMODIUM FALCIPARUM
}

\author{
Sutopo Hadi*, N. Noviany, Mita Rilyanti \\ Department of Chemistry, Faculty of Mathematics and Natural Sciences, \\ University of Lampung, Bandar Lampung, Indonesia 35145 \\ sutopo.hadi@fmipa.unila.ac.id
}

\begin{abstract}
Antimalarial activity study of organotin(IV) derivatives with nitrobenzoic acid derivatives used as ligands has been performed. The targeted compounds were prepared from their organotin(IV) chlorides via dibutyltin(IV) oxide, diphenyltin(IV) dihydroxide, and triphenyltin(IV) hydroxide intermediate products, followed by reacting the intermediate products with 2-nitrobenzoic acid. The antimalarial activity was performed against $P$. falciparum. The results showed that the $\mathrm{IC}_{50}$ values of dibutyiltin(IV) di-2nitrobenzoate, diphenyltin(IV) di-2-nitrobenzoate, and triphenyltin(IV) 2-nitrobenzoate were in $8.4 \times$ $10^{-3}, 5.3 \times 10^{-2}$, and $9.1 \times 10^{-3} \mu \mathrm{g} / \mathrm{ml}$, respectively. The $\mathrm{IC}_{50}$ values were slightly higher than the value for chloroquine $\left(2 \times 10^{-3} \mu \mathrm{g} / \mathrm{ml}\right)$ used as the positive control; however, one advantage is that all prepared organotin(IV) compounds were not resistant to Plasmodium, making the use of organotin(IV) as an antimalarial is possible. The results indicated that the derivative of triphenyltin(IV) was more potent when used as an antimalarial, as expected, and has potential to be developed as an antimalarial drug in the future.
\end{abstract}

Keywords: antimalarial activity, $\mathrm{IC}_{50}$, organotin(IV) nitrobenzoate, $P$. falciparum

\section{АНТИМАЛАРИСКА АКТИВНОСТ IN VITRO НА НЕКОИ СОЕДИНЕНИЈА НА ОРГАНОКАЛАЈ(IV) 2-НИТРОБЕНЗОАТ ВР3 PLASMODIUM FALCIPARUM}

Спроведено е испитување на антималариската активност на деривати на органокалај(IV) co нитробензоева кислеина употребени како лиганд. Целните соедиенија беа приготвени од нивните органокалај(IV) хлориди преку дибутилкалај(IV) оксид, дифенилкалај(IV) дихидроксид и трифенилкалај(IV) хидроксид како интермедијери, кои потоа реагираа со 2-нитробензоева киселина. Антималариската активност беше изведена врз P. falciparum. Резултатите покажуваат дека соодветните $\mathrm{IC}_{50}$ вредности на дибутилкалај(IV) ди-2-нитробензоат, дифенилкалај(IV) ди-2нитробензоат и трифенилкалај(IV) ди-2-нитробензоат изнесуваа $8,4 \times 10^{-3}, 5,3 \times 10^{-2}$ и $9,1 \times 10^{-3}$ $\mu \mathrm{g} / \mathrm{ml}$. Вредностите $\mathrm{IC}_{50}$ се нешто повисоки во однос на хлорохин $\left(2 \times 10^{-3} \mu \mathrm{g} / \mathrm{ml}\right)$ кој беше употребен како позитивна контрола. Меѓутоа, една предност на сите приготвени соединенија на органокалај(IV) е што Plasmodium не е резистентен на нив, што овозможува нивна употреба како антималариски средства. Резултатите укажуваат дека дериватот на трифенилкалај(IV) има поголема антималариска активност и има потенцијал во иднидна да се развие во антималариски лек.

Клучни зборови: антимлариска активност; IC 50; органокалај(IV) нитробензоат; $P$. falciparum 


\section{INTRODUCTION}

Organotin(IV) compounds continue to attract chemists because of their strong effects in many biological tests $[1,2]$. The main factor that affects their biological activities is determined by the number of groups and the organic groups attached to Sncenter [3], while the presence and nature of the anionic groups is a secondary factor [3]. Investigations of the coordination of carboxylates and their derivatives in organotin compounds have led to the isolation of new organotin(IV) carboxylates and carboxylate derivatives, which have shown interesting biological activities, including antitumor and anticancer [3-7], antimicrobial [58], antifungal [3, 8, 9], anticorrosion [10-13], and antiplasmodial [14] activities. The latest development of these compounds has led to the finding of antimalarial activities. The investigation of organotin(IV) as a possible antimalarial is still very challenging and has attracted much attention [14].

Malaria, a disease caused by Plasmodium, has been known for a century and continues to be a major public health problem in Indonesia and other tropical countries. Due to the wide effect caused by malaria, the World Health Organization (WHO) monitors this disease with a program called Roll Back Malaria (RBM), with focuses on immediate diagnoses and exact treatment to eradicate malaria $[15,16]$. Malaria cases in Indonesia from 20082016 were very high $[17,18]$. Based on the data released by the WHO in 2016, the rate of malaria incidence in Indonesia is $6 \%$ [18]. Previously, malaria treatments in Indonesia have used chloroquine and sulfadoxine-pirimetamine as the main drugs [17]; however, their use is now limited due to their resistances against malaria. Therefore, efforts to find new potent antimalarial drugs is required [14, $15]$.

Based on the fact that organotin(IV) compounds have been found to have promising antimalarial activity, in this paper, we report the application and antimalarial activity of organotin(IV) 2nitrobenzoates against $P$. falciparum.

\section{EXPERIMENTAL}

\subsection{Materials}

All reagents used were $\mathrm{AR}$ grade. Dibutyltin(IV) dichlorides $\left(\left[\left(n-\mathrm{C}_{4} \mathrm{H}_{9}\right)_{2} \mathrm{Cl}_{2}\right]\right)$, diphenyltin(IV) dichloride $\left(\left[\left(\mathrm{C}_{6} \mathrm{H}_{5}\right)_{2} \mathrm{Cl}_{2}\right]\right)$, triphenyltin(IV) chloride $\left(\left[\left(\mathrm{C}_{6} \mathrm{H}_{5}\right)_{3} \mathrm{Cl}\right]\right)$, 2-nitrobenzoic acid, and Roswell Park Memorial Institute (RPMI) medium were obtained from Sigma. Water (HPLC grade), sodium hydroxide $(\mathrm{NaOH})$, and methanol $\left(\mathrm{CH}_{3} \mathrm{OH}\right)$ were JT Baker products and were used without further purification.

\subsection{Characterization and instrumentation}

Microelemental analyses (CHNS) were performed on a Fision EA 1108 series elemental analyzer. Infrared (IR) spectra in the range of 4000$400 \mathrm{~cm}^{-1}$ were recorded on a Bruker VERTEX 70 Fourier-transform infrared (FT-IR) spectrophotometer with $\mathrm{KBr}$ discs. The ultraviolet (UV) spectra were recorded in the UV region and were measured using a UV-Shimadzu UV-245 Spectrophotometer. Measurements were performed in $1 \mathrm{ml}$ quartz cells. Solutions were prepared using methanol as the solvent with a concentration of $1.0 \times 10^{-4} \mathrm{M}$.

${ }^{1} \mathrm{H}$ and ${ }^{13} \mathrm{C}$ nuclear magnetic resonance (NMR) spectra were recorded on a Bruker AV 600 $\mathrm{MHz}$ NMR (600 MHz for ${ }^{1} \mathrm{H}$ and $150 \mathrm{MHz}$ for ${ }^{13} \mathrm{C}$ ). All experiments were run in dimethyl sulfoxide (DMSO)- $\mathrm{D}_{6}$ at $298 \mathrm{~K}$. The number of runs used for ${ }^{1} \mathrm{H}$ experiments were 32 with reference at DMSO signal at $2.5 \mathrm{ppm}$, while the ${ }^{13} \mathrm{C}$ spectra involved 1000-4000 scans with the reference DMSO signal at $39.5 \mathrm{ppm}$.

\subsection{Preparation of organotin(IV) nitrobenzoates}

The organotin(IV) 2-nitrobenzoates used in this work were prepared based on the procedure previously reported $[6-10,12,13]$ and adapted from the work by Szorcsik et al. [19]. An example procedure in the preparation of diphenyltin(IV) di2-nitrobenzoate is as follows:

Approximately $0.8 \mathrm{~g}(0.02 \mathrm{~mol}) \mathrm{NaOH}$ was added to $3.44 \mathrm{~g}(0.01 \mathrm{~mol})\left[\left(\mathrm{C}_{6} \mathrm{H}_{5}\right)_{2} \mathrm{SnCl}_{2}\right](4)$ in 50 $\mathrm{ml}$ methanol. The reaction mixture was stirred for about 60 minutes. The compound $\left[\left(\mathrm{C}_{6} \mathrm{H}_{5}\right)_{2} \mathrm{Sn}(\mathrm{OH})_{2}\right]$ (5) was precipitated out as a white solid, filtered, and dried in vacuo until analysis and further reaction. The average yield was $2.92 \mathrm{~g}(95 \%)$.

Approximately 2 mole equivalents of 2 nitrobenzoic acid $(0.501 \mathrm{~g})$ was added to $0.4605 \mathrm{~g}$ (1.5 mmol) of compound 2 in $50 \mathrm{ml}$ of methanol, and the solution was refluxed for 4 hours at 60 $62^{\circ} \mathrm{C}$. After removal of the solvent by rotary evaporation, the produced compounds $\left[\left(\mathrm{C}_{6} \mathrm{H}_{5}\right)_{2} \mathrm{Sn}(2\right.$ $\left.\mathrm{OOCC}_{6} \mathrm{H}_{4}\left(\mathrm{NO}_{2}\right)_{2}\right]$ were dried in vacuo until analysis and further use for in vitro antimalarial activity studies. The yield was $1.67 \mathrm{~g}$ (greater than $~ 92 \%$ ).

A similar procedure was also adapted in the preparation of dibutyltin(IV) and triphenyltin(IV) derivatives, $\left[\left(n-\mathrm{C}_{4} \mathrm{H}_{9}\right)_{2} \mathrm{Sn}\left(2-\mathrm{OOCC}_{6} \mathrm{H}_{4} \mathrm{NO}_{2}\right)_{2}\right] \quad$ (3) and $\left[\left(\mathrm{C}_{6} \mathrm{H}_{5}\right)_{3} \mathrm{Sn}\left(2-\mathrm{OOCC}_{6} \mathrm{H}_{4} \mathrm{NO}_{2}\right)\right](9)$, respective- 
ly. For triphenyltin(IV), only one mole equivalent of the nitrobenzoic acid was added.

\subsection{In vitro antimalarial bioactivity assays}

The in vitro antimalarial assays were performed at the Institute of Tropical Disease, Universitas Airlangga, Surabaya, Indonesia. The malaria parasite $P$. falciparum 3D7 clone was essentially propagated according to a previously published procedure [11]. Briefly, parasite cultures were propagated in tissue culture flasks containing RPMI-1640 medium supplemented with $25 \mu \mathrm{g} / \mathrm{ml}$ gentamycin, $50 \mu \mathrm{g} / \mathrm{ml}$ hypoxanthine, $25 \mu \mathrm{mM}$ Hepes buffer, $25 \mathrm{mM}$ sodium bicarbonate, $10 \%$ $\mathrm{AB}+$ human serum, $5 \%$ haematocrit, and human erythrocytes with the $\mathrm{pH}$ maintained at 7.4. Each compound tested was first dissolved in DMSO and diluted to different concentrations by adding complete malaria medium. Chloroquine was used as a positive control. To determine the antiplasmodial activity of each isolated compound, parasites were placed in a 24-well culture plate in the presence of each compound, where the concentration was 10 $\mu \mathrm{g} / \mathrm{ml}, 1 \mu \mathrm{g} / \mathrm{ml}, 0.1 \mu \mathrm{g} / \mathrm{ml}, 0.01 \mu \mathrm{g} / \mathrm{ml}$, or 0.001 $\mu \mathrm{g} / \mathrm{ml}$. The parasite growth was monitored by making a blood smear that was fixed with methanol and stained with Giemsa. Total parasitaemia was calculated as the number of observed parasites divided by the total erythrocyte, multiplied by 100
$\%$. The concentration response parasite growth data was calculated by linear regression provided by SYSTAT Sigma Plot using the $50 \%$ inhibitory concentration $\left(\mathrm{IC}_{50}\right)$. The $\mathrm{IC}_{50}$ value is defined as the concentration of a compound producing $50 \%$ growth inhibition relative to the untreated control.

\section{RESULTS AND DISCUSSION}

Following the preparation of the organotin(IV) carboxylate compounds, preparation and characterization of three organotin(IV) 2-nitrobenzoates of dibutyltin(IV) di-2-nitrobenzoate [ $(n-$ $\left.\mathrm{C}_{4} \mathrm{H}_{9}\right)_{2} \mathrm{Sn}\left(2-\mathrm{OOCC}_{6} \mathrm{H}_{4} \mathrm{NO}_{2}\right)_{2}$ ] (3), diphenyltin(IV) di-2-nitrobenzoate $\left[\left(\mathrm{C}_{6} \mathrm{H}_{5}\right)_{2} \mathrm{Sn}\left(2-\mathrm{OOCC}_{6} \mathrm{H}_{4} \mathrm{NO}_{2}\right)_{2}\right]$ (6), and triphenyltin(IV) 2-nitrobenzoate $\left[\left(\mathrm{C}_{6} \mathrm{H}_{5}\right)_{3} \mathrm{Sn}\left(2-\mathrm{OOCC}_{6} \mathrm{H}_{4} \mathrm{NO}_{2}\right)\right](9)$ were successfully performed from their chlorides $\left[\left(n-\mathrm{C}_{4} \mathrm{H}_{9}\right)_{2} \mathrm{SnCl}_{2}\right]$ (1), $\left[\left(\mathrm{C}_{6} \mathrm{H}_{5}\right)_{2} \mathrm{SnCl}_{2}\right](4)$, and $\left[\left(\mathrm{C}_{6} \mathrm{H}_{5}\right)_{3} \mathrm{SnCl}\right]$ (7), respectively, where all reactions in all cases were performed via $\left[\left(n-\mathrm{C}_{4} \mathrm{H}_{9}\right)_{2} \mathrm{SnO}\right](2),\left[\left(\mathrm{C}_{6} \mathrm{H}_{5}\right)_{2} \mathrm{Sn}(\mathrm{OH})_{2}\right]$ (5) and $\left[\left(\mathrm{C}_{6} \mathrm{H}_{5}\right)_{3} \mathrm{SnOH}\right](8)$ in the same way as the procedure previously reported $[6-9,12,13]$. An example of the reaction step that occurred in the preparation of dibutyltin(IV) dinitrobenzoate is shown in Figure 1. The microanalysis data for all compounds synthesized are provided in Table 1 . In general, all values obtained were very good and close to the calculated values.

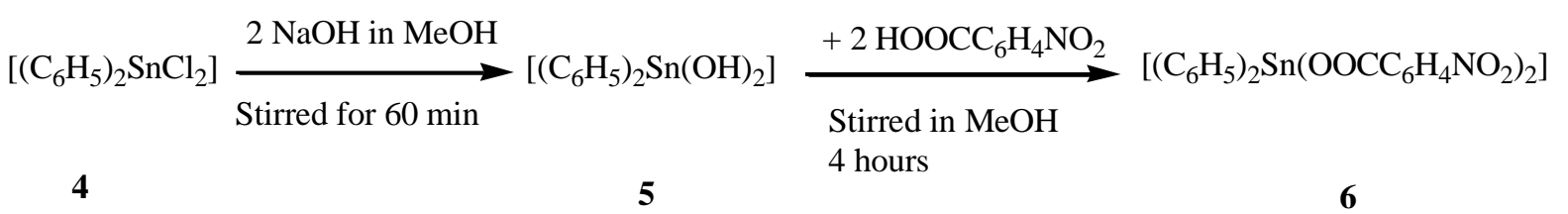

Fig. 1. Scheme for the preparation of organotin(IV) di-2-nitrobenzoate

Table 1

The microanalytical data of the organotin(IV) compounds synthesized

\begin{tabular}{|c|c|c|c|}
\hline \multirow{2}{*}{ Compound } & \multicolumn{3}{|c|}{ Elemental analysis found (calculated) } \\
\hline & $\mathrm{C}$ & $\mathrm{H}$ & $\mathrm{N}$ \\
\hline$\left[\left(n-\mathrm{C}_{4} \mathrm{H}_{9}\right)_{2} \mathrm{SnCl}_{2}\right](\mathbf{1})$ & $31.4(31.6)$ & $6.0(5.9)$ & \\
\hline$\left[\left(n-\mathrm{C}_{4} \mathrm{H}_{9}\right)_{2} \mathrm{SnO}\right](2)$ & $38.6(38.6)$ & $7.1(7.3)$ & \\
\hline$\left[\left(n-\mathrm{C}_{4} \mathrm{H}_{9}\right)_{2} \mathrm{Sn}\left(2-\mathrm{OOCC}_{6} \mathrm{H}_{4}\left(\mathrm{NO}_{2}\right)\right)_{2}\right](\mathbf{3})$ & $46.8(46.7)$ & $4.7(4.6)$ & $4.8(4.96)$ \\
\hline$\left[\left(\mathrm{C}_{6} \mathrm{H}_{5}\right)_{2} \mathrm{SnCl}_{2}\right](\mathbf{4})$ & $41.7(41.9)$ & $2.8(2.9)$ & \\
\hline$\left[\left(\mathrm{C}_{6} \mathrm{H}_{5}\right)_{2} \mathrm{Sn}(\mathrm{OH})_{2}\right](\mathbf{5})$ & $46.5(46.9)$ & $3.8(3.9)$ & \\
\hline$\left[\left(\mathrm{C}_{6} \mathrm{H}_{5}\right)_{2} \mathrm{Sn}\left(2-\mathrm{OOCC}_{6} \mathrm{H}_{4}\left(\mathrm{NO}_{2}\right)_{2}\right](6)\right.$ & $51.3(51.6)$ & $3.1(2.98)$ & $4.5(4.63)$ \\
\hline$\left[\left(\mathrm{C}_{6} \mathrm{H}_{5}\right)_{3} \mathrm{SnCl}\right](\mathbf{7})$ & $55.8(56.1)$ & $4.0(3.9)$ & \\
\hline$\left[\left(\mathrm{C}_{6} \mathrm{H}_{5}\right)_{3} \mathrm{Sn}(\mathrm{OH})\right](\mathbf{8})$ & $58.4(58.9)$ & $4.3(4.4)$ & \\
\hline$\left[\left(\mathrm{C}_{6} \mathrm{H}_{5}\right)_{3} \mathrm{Sn}\left(2-\mathrm{OOCC}_{6} \mathrm{H}_{4}\left(\mathrm{NO}_{2}\right)\right](\mathbf{9})\right.$ & $57.2(58.1)$ & $3.8(3.68)$ & $2.6(2.71)$ \\
\hline
\end{tabular}


Spectroscopy techniques have been used to characterize all synthesized compounds. The important FT-IR data and their assignments are presented in Table 2. The characteristic band of the starting materials $(1,4,7)$ is the strong stretching band of the $\mathrm{Sn}-\mathrm{Cl}$ bond at $390-310 \mathrm{~cm}^{-1}$. In 1, for example, the $\mathrm{Sn}-\mathrm{Cl}$ bond appeared at a frequency of $334.2 \mathrm{~cm}^{-1}$. The other characteristic bands of this compound appear as the stretching band from butyl ligands at $1069 \mathrm{~cm}^{-1}$ and the bending vibration of the $\mathrm{C}-\mathrm{H}$ aliphatic stretch of the butyl at a frequency of 2956-2865 $\mathrm{cm}^{-1}$. When compound 1was converted to compound 2, the main stretching band of $\mathrm{Sn}-\mathrm{Cl}$ disappeared and a new strong band at a frequency of $417.4 \mathrm{~cm}^{-1}$ appeared as one of the main stretching bands. This band is characteristic of the $\mathrm{Sn}-\mathrm{O}$ bond in compound 2 . The stretching band and the bending vibrations due to the presence of butyls were still observed, as expected, although the frequencies were a little shifted. The formation of dibutyltin(IV) di-2-nitrobenzoate compounds $\left[\left(n-\mathrm{C}_{4} \mathrm{H}_{9}\right)_{2} \mathrm{Sn}\left(2-\mathrm{OOCC}_{6} \mathrm{H}_{4}\left(\mathrm{NO}_{2}\right)\right)_{2}\right]$ (3) was confirmed by the strong asymmetric stretching bands of the carboxylate groups, which occurred at ca. $1400 \mathrm{~cm}^{-1}$, and the symmetric stretch at ca. $1600 \mathrm{~cm}^{-1}$, as well as the present of $\mathrm{Sn}-\mathrm{O}$ stretching of the acid at $435 \mathrm{~cm}^{-1}$. The appearance of these bands confirmed the success of the substitution reaction $[6-9,12,13]$.
UV spectroscopy analyses of all compounds were utilized to obtain $\lambda_{\max }$. The data obtained is shown in Table 3. It is clear that there was a shifting change in the $\lambda_{\max }$ for each compound in any step of the reaction. For example, compound $\mathbf{1}$ had a $\lambda_{\max }$ of $210.7 \mathrm{~nm}$, while compound $\mathbf{2}$ had a $\lambda_{\max }$ of $202.9 \mathrm{~nm}$. This information indicates that there was a shift to a shorter $\lambda_{\max }$ value when the conversion of compound $\mathbf{1}$ to $\mathbf{2}$ took place. The wavelength shift to a shorter $\lambda_{\max }$ could occur due to either the solvent used in the measurement or the effect of an auxochrome of the ligand. However, in this study, as the solvent used for all measurements was the same (methanol), the change in the $\lambda_{\max }$ that occurred must have been due to the auxochrome effect. In the case of compound $\mathbf{1}$ and $\mathbf{2}$, there was an oxide group, which has a bigger electron drawing effect in compound $\mathbf{2}$ compared to the chloride group in compound 1. As a result, the electron transition in $\mathbf{2}$ is too difficult to occur. Thus, the measured $\lambda_{\max }$ was shorter in compound 2 compared to compound 1 [20-22]. Similar results were observed for other changes, as can be seen in Table 3. For example, in compound $\mathbf{3}$, the electron drawing effect of $2-\mathrm{C}_{6} \mathrm{H}_{4}\left(\mathrm{NO}_{2}\right) \mathrm{COOH}$ was less than that of the chloride in compound $\mathbf{1}$; therefore, the electron transition in this molecule will be easier (the energy required is less), thus producing a longer $\lambda_{\max }(291.3 \mathrm{~nm})$.

Table 2

The characteristic and important IR bands of the organotin(IV) compounds $\left(\mathrm{cm}^{-1}\right)$ synthesized

\begin{tabular}{lcccc}
\hline \hline Compound & $\mathbf{3}$ & $\mathbf{6}$ & $\mathbf{9}$ & References \\
\hline Sn-O & 434.4 & 594.0 & 735.42 & $800-400$ \\
$\mathrm{Sn}-\mathrm{O}-\mathrm{C}$ & 1029.1 & 1238.2 & 1243.4 & $1050-900$ \\
$\mathrm{Sn}-\mathrm{Bu}$ & 674.4 & - & - & $740-660$ \\
$\mathrm{CO}_{2}$ asym & 1419.1 & 1531.7 & 1557.5 & $1600-1400$ \\
$\mathrm{CO}_{2}$ sym & 1558.1 & 1659.3 & 1630.4 & $1700-1550$ \\
$\mathrm{C}-\mathrm{H}$ aliphatic & $2954-2860$ & - & - & $2960-2850$ \\
Phenyl & - & $1467.0 ; 750.7$ & $1428.4 ; 729.1$ & 1450,730 \\
\hline \hline
\end{tabular}

T a ble 3

The $\lambda_{\max }$ of the UV-Vis spectra of the organotin(IV)2-nitrobenzoate compounds

\begin{tabular}{lccc}
\hline \hline \multirow{2}{*}{ Compound } & \multicolumn{3}{c}{$\lambda \max (\mathrm{nm})$} \\
\cline { 2 - 4 } & $\pi-\pi^{*}$ & $\mathrm{n}-\pi$ & $\begin{array}{c}\text { Benzene ring } \\
\text { secondary band }\end{array}$ \\
\hline$\left[\left(n-\mathrm{C}_{4} \mathrm{H}_{9}\right)_{2} \mathrm{SnCl}_{2}\right](\mathbf{1})$ & 210.7 & - & - \\
{$\left[\left(n-\mathrm{C}_{4} \mathrm{H}_{9}\right)_{2} \mathrm{SnO}\right](\mathbf{2})$} & 202.9 & - & - \\
{$\left[\left(n-\mathrm{C}_{4} \mathrm{H}_{9}\right)_{2} \mathrm{Sn}\left(2-\mathrm{OOCC}_{6} \mathrm{H}_{4}\left(\mathrm{NO}_{2}\right)\right)_{2}\right](\mathbf{3})$} & - & 291.3 & - \\
{$\left[\left(\mathrm{C}_{6} \mathrm{H}_{5}\right)_{2} \mathrm{Sn}\left(2-\mathrm{OOCC}_{6} \mathrm{H}_{4}\left(\mathrm{NO}_{2}\right)_{2}\right](\mathbf{6})\right.$} & 201 & 299.2 & 407 \\
{$\left[\left(\mathrm{C}_{6} \mathrm{H}_{5}\right)_{3} \mathrm{Sn}\left(2-\mathrm{OOCC}_{6} \mathrm{H}_{4}\left(\mathrm{NO}_{2}\right)\right](\mathbf{9})\right)$} & 204 & 303.8 & 410 \\
\hline \hline
\end{tabular}


The analysis of the ${ }^{1} \mathrm{H}$ and ${ }^{13} \mathrm{C}$ chemical shifts of the prepared compounds is shown in Table 4 and based on the numbering of the proposed structure as in Figure 2. Certain signals in the recorded spectra were carefully characterized. The chemical shift $(\delta)$ of the butyl protons attached to the tin metal appeared at $0.92 \mathrm{ppm}$ for $\mathrm{H} \delta$ and 1.36 - $1.61 \mathrm{ppm}$ for $\mathrm{H} \alpha$ and H$\beta$.The carbons of the butyl ligands were observed at positions comparable to other similar compounds reported previously [7, $12,13,19,21-23]$. The chemical shift of the phenyl protons attached to the tin metal appeared at $7.35-7.58 \mathrm{ppm}$, while the carbon of the carboxyl group of all compounds appeared in the region of $176 \mathrm{ppm}$, as expected [13, 20, 22-24]. The carbon atoms of the phenyl ligand appeared in $\delta$ of $131-$ $126 \mathrm{ppm}$, while the carbons in the nitrobenzoate derivatives appeared in $\delta$ range of $140-130 \mathrm{ppm}$, close to the reported values of similar compounds [13, 20, 22-24].

In our previous study on the antifungal and anticancer activity of the compounds reported here $[6-9,12,13]$, it has been shown that optimal activity of the antifungals and anticancers is associated with the number of carbon atoms of the ligand present in the organotin(IV) [6-9, 12, 13, 25], where the derivative of triphenyltin(IV) carboxylate, which contains 18 carbon atoms, has the highest activity $[6-9,12,13,25]$. The same phenomena, interestingly, was also observed in this study.

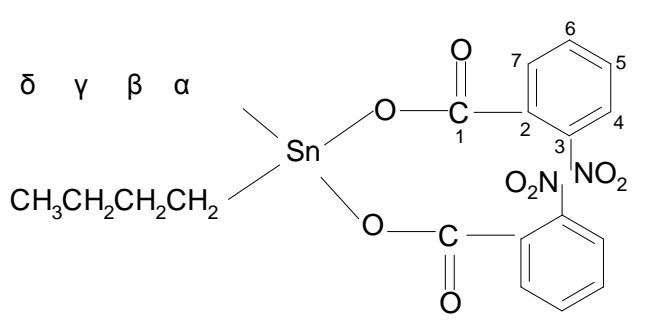

3

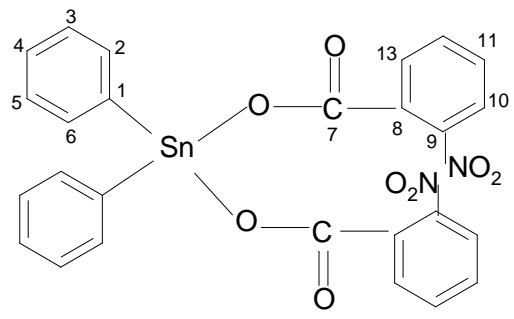

6

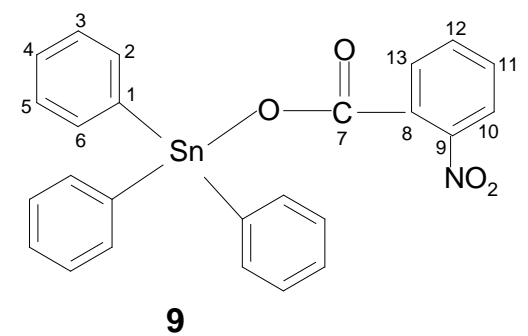

Fig. 2.The proposed structures of the synthesized compounds and the suggested numbering of carbons in each compound

Table 4

${ }^{1} \mathrm{H}$ and ${ }^{13} \mathrm{C}$ spectra of the compounds synthesized

\begin{tabular}{|c|c|c|c|}
\hline Compounds & $\begin{array}{l}\text { H in butyl or phenyl } \\
(\mathrm{ppm})\end{array}$ & $\begin{array}{l}\mathrm{H} \text { in benzoate } \\
(\mathrm{ppm})\end{array}$ & $\begin{array}{l}\mathrm{C} \text { in butyl, phenyl and benzoate } \\
\text { (ppm) }\end{array}$ \\
\hline$\left[\left(n-\mathrm{C}_{4} \mathrm{H}_{9}\right)_{2} \mathrm{Sn}\left(2-\mathrm{OOCC}_{6} \mathrm{H}_{4}\left(\mathrm{NO}_{2}\right)\right)_{2}\right](\mathbf{3})$ & $\begin{array}{l}\mathrm{H} \alpha \text { \& H } \beta: 1.36-1.61 \\
(\mathrm{~m}) ; \mathrm{H} \gamma: 1.29(\mathrm{~m}) \\
\mathrm{H} \delta: 0.92(\mathrm{t})\end{array}$ & $7.33-7.85(\mathrm{~m})$ & $\begin{array}{l}\mathrm{C} \alpha: 21.1 ; \mathrm{C} \beta: 26.5 ; \mathrm{C} \gamma: 25.8 ; \mathrm{C} \delta: \\
14.1 ; \mathrm{C} 1: 174.8 ; \mathrm{C} 2: 139.2 ; \mathrm{C} 3 \text { \& } \\
\mathrm{C} 7: 129.6 ; \mathrm{C} 4 \text { \& } \mathrm{C} 6: 128.5 ; \mathrm{C} 5: \\
125.2\end{array}$ \\
\hline$\left[\left(\mathrm{C}_{6} \mathrm{H}_{5}\right)_{2} \mathrm{Sn}\left(2-\mathrm{OOCC}_{6} \mathrm{H}_{4}\left(\mathrm{NO}_{2}\right)_{2}\right](\mathbf{6})\right.$ & $\begin{array}{l}\mathrm{H} 2 \text { \& H6 } 7.58(\mathrm{~d} \\
4 \mathrm{H}) ; \mathrm{H} 3 \text { \& H5 } 7.47 \\
(\mathrm{t}, 4 \mathrm{H}) ; \mathrm{H} 4: 7.35(\mathrm{t}, \\
2 \mathrm{H})\end{array}$ & $7.80-7.92(\mathrm{~m})$ & $\begin{array}{l}\text { C1-6 (phen): 131.6-126.8; C7: } \\
\text { 175.6; C8: 139.4; C9 \& C13: 130.1; } \\
\text { C10 \& C12: 129.2; C11: } 128.4\end{array}$ \\
\hline$\left[\left(\mathrm{C}_{6} \mathrm{H}_{5}\right)_{3} \mathrm{Sn}\left(2-\mathrm{OOCC}_{6} \mathrm{H}_{4}\left(\mathrm{NO}_{2}\right)\right](\mathbf{9})\right)$ & $\begin{array}{l}\mathrm{H} 2 \text { \& H6 } 7.56(\mathrm{~d}, \\
6 \mathrm{H}) ; \mathrm{H} 3 \text { \& H5 } 7.44 \\
(\mathrm{t}, 6 \mathrm{H}) ; \mathrm{H} 4: 7.01(\mathrm{t}, \\
3 \mathrm{H})\end{array}$ & $7.80-7.9(d)$ & $\begin{array}{l}\text { C1-6 (phen): 131.0-126.2; C7: } \\
\text { 175.2; C8: 139.1; C9 \& C13: 130.2; } \\
\text { C10 \& C12: 128.5; C11: } 128.1\end{array}$ \\
\hline
\end{tabular}

As shown in Table 5, the derivatives of triphenyltin(IV) compounds showed the highest antimalarial activitesin the series, and the diphenyltin(IV) compounds were stronger inhibitors than those of dibutyltin(IV) compounds, similar to pre- vious reports $[12,13]$. Thus, the number of carbon atoms present, as well as the type of the ligands, has a significant effect on the antimalarial activity of the organotin(IV) compounds tested [25]. 
Table 5

The $I C_{50}$ values of the compounds tested

\begin{tabular}{ll}
\hline \hline Compounds & $\mathrm{IC}_{50}(\mu \mathrm{g} / \mathrm{ml})$ \\
\hline Chloroquine & $2.0 \times 10^{-3}$ \\
{$\left[\left(n-\mathrm{C}_{4} \mathrm{H}_{9}\right)_{2} \mathrm{Sn}\left(2-\mathrm{OOCC}_{6} \mathrm{H}_{4}\left(\mathrm{NO}_{2}\right)\right)_{2}\right](3)$} & $8.4 \times 10^{-2}$ \\
{$\left[\left(\mathrm{C}_{6} \mathrm{H}_{5}\right)_{2} \mathrm{Sn}\left(2-\mathrm{OOCC}_{6} \mathrm{H}_{4}\left(\mathrm{NO}_{2}\right)_{2}\right](\mathbf{6})\right.$} & $5.3 \times 10^{-2}$ \\
{$\left[\left(\mathrm{C}_{6} \mathrm{H}_{5}\right)_{3} \mathrm{Sn}\left(2-\mathrm{OOCC}_{6} \mathrm{H}_{4}\left(\mathrm{NO}_{2}\right)\right](\mathbf{9})\right)$} & $9.1 \times 10^{-3}$ \\
\hline \hline
\end{tabular}

It was also observed that the synthesized organotin(IV) 2-nitrobenzoate compounds exhibited much higher antimalarial activities compared to those of the ligands, starting materials, and intermediate products. In this respect, our results are consistent with a well-known fact that many biologically active compounds become more active upon complexation [26]. According to Crowe, the actual biological activity of diorganotin compounds of the type RR'SnXY ( $\mathrm{R}$ and $\mathrm{R}^{\prime}=$ alkyl or aryl, $\mathrm{X}$ and $\mathrm{Y}=$ anions) is determined solely by the RR' $\mathrm{Sn}^{2+}$ moiety [27].

\section{CONCLUSION}

Organotin(IV) nitrobenzoate compounds were successfully prepared and had promising results regarding their use as antimalarial drugs. The fact that triphenyltin(IV) nitrobenzoate derivatives have the highest antimalarial activity was in line with other data relating the number of carbon atoms present in the compound. Further studies using artemisinin-based combination therapy (ACT) as the positive control, as well as comprehensive antimalarial experiments, are being carried out to find the best explanation for this phenomenon.

Acknowledgments. The authors are grateful to Universitas Lampung for funding this project to be undertaken through Professor Research Scheme 2017 with contract number 806/UN26.21/PP/2017 and Penelitian Berbasis Kompetensi (Competency Research Grant Scheme) 2018 from Directorate of Research and Community Services, The Ministry of Research, Technology and Higher Education, Indonesia, with contract number 384/UN26.21/PN/2018, 12 February 2018. Special thanks must go to Directorate of Intellectual Property Right, Directorate General of Strenghening Research and Development for supporting the presentation of this paper in the international EastWest Chemistry Conference (EWCC) Lviv, Ukraine, 2018. Thanks also go to Prof. Bohari M. Yamin, University Kebangsaan, Malaysia, for help with microanalysis and Prof. Dr. Hasnah Osman of School of Chemistry, University of Sains, Malaysia, for NMR experimentation.

\section{REFERENCES}

[1] E. R. T. Tiekink, Structural chemistry of organotin carboxylates: A review of the crystallographic literature, App. Organomet. Chem. 5, 1-30 (1991).

[2] K. Shahid, S. Ali, S. Shahzadi, Z. Akhtar, Organotin(IV) complexes on aniline derivaties, Part II: Synthesis and spectroscopic characterization of organotin(IV) derivatives of 2-[4-bromoanailine)carboxyl]benzoic acid, Turk. J. Chem., 27, 209-215 (2003).

[3] L. Pellerito, L. Nagy, Organotin(IV $)^{\mathrm{n+}}$ complexes formed with biologically active ligands: equilibrium and structural studies, and some biological aspects. Coord. Chem. Rev., 224, 111-150 (2002).

[4] B. Gleeson, J. Claffey, D. Ertler, M. Hogan, H. MüllerBunz, F. Paradisi, D. Wallis, and M. Tacke, Novel organotin antibacterial and anticancer drugs, Polyhedron, 27, 3619-3624 (2008).

[5] W. Rehman, A. Badshah, S. Khan, L. T. A. Tuyet, Synthesis, characterization, antimicrobial and antitumor screening of some diorganotin(IV) complexes of 2-[(9HPurin-6-ylimino)]-phenol, Eur. J. Med. Chem., 44, 3981-3985(2009).

[6] S. Hadi, M. Rilyanti, Synthesis and in vitro anticancer activity of some organotin(IV)benzoate compounds, Orient. J. Chem., 26, 775-779 (2010).

[7] S. Hadi, M. Rilyanti, Suharso, In Vitro activity and comparative studies of some organotin(IV) benzoate derivatives against leukemia cancer cell: L-1210, Indo. J. Chem., 12, 172-177 (2012).

[8] S. Hadi, B. Irawan, Efri, The antifungal activity test of some organotin(IV) carboxylates, J. Appl. Sci. Res., 4, 1521-1525(2008).

[9] S. Hadi, M. Rilyanti, Nurhasanah, Comparative study on the antifungal activity of some di- and tributyltin(IV) carboxylate compounds, Modern Appl. Sci.,3 (2), 12-17 (2009).

[10] R. Singh, P. Chaudary, N. K. Khausik, A Review: Organotin compounds in corrosion inhibition, Rev. Inorg. Chem., 30, 275-294 (2010).

[11] R. B. Rastogi, M. M. Singh, K. Singh, M. Yadav, Organotin dithiobiurets as corrosion inhibitors for mildsteel-dimethyl sulfoxide containing $\mathrm{HCl}, A f r . J$. Pure Appl. Chem.,5(2), 19-33(2011).

[12] H. Kurniasiah, M. Nurissalam, B. Iswantoro, H. Afiyani, H. I. Qudus, S. Hadi., The Synthesis, characterization and comparative anticorrosion study of some organotin(IV) 4-chlorobenzoates, Orient. J. Chem., 31, 2377-2383 (2015).

[13] S. Hadi, H. Afriyani, W. D. Anggraini, H. I. Qudus, T. Suhartati, The synthesis and potency study of some dibutyltin(IV) dinitrobenzoate compounds as corrosion inhibitor for mild steel HRP in DMSO-HCl solution, Asian J. Chem., 27, 1509-1512 (2015).

[14] C. Hansch, R. P. Verma, Larvicidal activities of some organotin compounds on mosquito larvae: A QSAR study, Eur. J. Med. Chem., 44, 260-273 (2009). 
[15] WHO, Roll Back Malaria Program. Available at http://www.who.int/malaria/en/. 2011. [Verified April 20, 2011]

[16] A. A. James, Mosquito molecular genetics: the hands that feed bite back, Science, 257, 37-38 (1992).

[17] I. R. F. Elyazar, S. I. Hay, J. K. Baird Malaria distribution, prevalence, drug resistance and control in Indonesia, Adv Parasitol., 74, 41-175 (2011).

[18] WHO. Malaria Profile of Indonesia. http://www.who. int/malaria/publications/country-profiles/profile_idn_en. pdf. 2016 (Verifed on October 5, 2018)

[19] A. Szorcsik, L. Nagy, K. Gadja-Schrantz, L. Pellerito, E. Nagy, E. T. Edelmann, Structural studies on organotin(IV) complexes formed with ligands containing $\{\mathrm{S}$, N, O\} donor atoms, J. Radioanal. Nucl. Chem. 252, 523-530 (2002).

[20] M. Nath, R. Yadav, M. Gielen, H. Dalil, D. de Vos, G. Eng, Synthesis, characteristic spectral studies and in vitro antimicrobial and antitumour activities of organotin(IV) complexes of Schiff bases derived from aminoacids, Appl. Organometal. Chem., 11, 727-736 (1997).

[21] Sudjadi, The Structure Determination of Organic Compounds. Ghalia Publishers, 1985. (In Indonesian).
[22] M. Rilyanti, S. Hadi, Synthesis, characterization and thermal stability of complex cis-[Co(bipy $\left.)_{2}(\mathrm{CN})_{2}\right]$ and its interaction with $\mathrm{NO}_{2}$ gas, Russ. J. Inorg. Chem., 56, 418-421 (2011).

[23] S. Hadi, T. G. Appleton, G. A. Ayoko, Reactions of fac$\left[\mathrm{PtMe}_{2}(\mathrm{OMe})\left(\mathrm{H}_{2} \mathrm{O}\right)_{3}\right]^{+}$with halide ions: effect of halide trans effect on methoxide hydrolysis, Inorg. Chim. Acta., 352, 201-207 (2003).

[24] S. Hadi, T. G. Appleton, Reactions of cisplatin hydrolytes, cis- $\left[\mathrm{Pt}\left({ }^{15} \mathrm{NH}_{3}\right)_{2}\left(\mathrm{H}_{2} \mathrm{O}\right)_{2}\right]^{2+}$, with $\mathrm{N}$-acetyl-Lcysteine, Russ. J. Inorg. Chem., 55, 223-228 (2010).

[25] Z. H. Chohan, A. Rauf, Some biologically active mixed ligand complexes of $\mathrm{Co}(\mathrm{II}), \mathrm{Cu}(\mathrm{II})$ and $\mathrm{Ni}(\mathrm{II})$ with $\mathrm{ONO}$, NNO and SNO donor nicotinoylhydrazine-derived ligands, Synth. React. Inorg. Met.-Org. Chem., 26, 591604 (1996).

[26] H. Gershon, Antifungal activity of bischelates of 5-, 7-, and 5,7-halogenated 8-quinols with copper(II). Determination of the long and short acces of the pores in the fungal spore wall, J. Med. Chem., 17, 824-827 (1974).

[27] A. J. Crowe, The antitumour activity of tin compounds; in Gielen M., (Ed.) Metal-Based Drugs, 1, 103-149 (1989). 
